\title{
The Correlation between miR-122 and Lipoprotein Lipase Expression in Chronic Hepatitis C Patients
}

\author{
Malgorzata Sidorkiewicz (D), Martyna Grek-Kowalinska, and Anna Piekarska \\ Medical University of Lodz, Poland \\ Correspondence should be addressed to Malgorzata Sidorkiewicz; malgorzata.sidorkiewicz@umed.lodz.pl
}

Received 15 February 2018; Revised 18 June 2018; Accepted 26 June 2018; Published 24 July 2018

Academic Editor: Tetsuro Shimakami

Copyright (c) 2018 Malgorzata Sidorkiewicz et al. This is an open access article distributed under the Creative Commons Attribution License, which permits unrestricted use, distribution, and reproduction in any medium, provided the original work is properly cited.

\begin{abstract}
Chronic HCV infection is strictly associated with host lipid/lipoprotein metabolism disorders. The study aimed to analyze the relationship between viral load, lipid profile, IFN $\gamma$, and the expression of miR-122 and LPL in the liver and PBMCs. Sera, PBMCs, and matching liver biopsies from 17 chronic hepatitis $\mathrm{C}$ patients were enrolled in this study. Collected data shows that liver (not PBMCs) miR-122 expression is positively correlated with HCV RNA load and IFN $\gamma$ and reversely with LPL expression in CHC patients. Presented, for the first time, in this study, the reverse correlation of miR-122 and LPL expression in liver; miR-122 and LPL seem to be important factors of $\mathrm{CHC}$ infection.
\end{abstract}

\section{Introduction}

Hepatitis C virus (HCV), with an estimated over 185 million people infected worldwide [1], is the major etiological cause of chronic hepatitis. Chronic hepatitis $\mathrm{C}(\mathrm{CHC})$ is directly associated with development of liver cirrhosis and hepatoma. HCV RNA triggers production of interferon gamma (IFN $\gamma$ ) but is often abrogated in CHC patients [2]. Reduced IFN $\gamma$ level implicates an immunological impairment that in turn consolidates the state of chronicity.

HCV infection affects host lipids/lipoproteins homeostasis. Alteration of metabolism seems to be essential for the HCV entire "life cycle": entry, replication, and the secretory pathway [3]. Circulating HCV virions are associated with VLDL and LDL, designated as lipo-viro-particles. Lipoprotein lipase (LPL) that catalyzes triglyceride (TG) hydrolysis of chylomicrons and VLDL has been identified as a promising host factor against HCV infection [4]. Lipo-viro HCV particles constitute effective substrate for LPL; thus reduction of $\mathrm{HCV}$ infectivity can be achieved by modifying the virionassociated lipid composition [5]. Additionally, LPL increases the binding capacity of HCV particles and reduces infectivity of the virus, possibly by blocking virions on the surface of cells [6]. Also, LPL-induced peroxisomal proliferatorsactivated receptor- $\alpha$ (PPAR- $\alpha$ ) signaling pathway activation was suggested as a factor that suppresses HCV infection [7].
Previous reports underscore the importance of miR-122 in liver biology and in the control of HCV infection (for review [8]). miR-122 exerts in vitro a positive effect on HCV replication through a direct interaction with 5'UTR region of viral genome. Inhibition of miR-122 reduces serum cholesterol level [9]. HCV RNA sequences were detected in vivo, not only in hepatocytes but also in fresh peripheral blood mononuclear cell (PBMC) preparations from $\mathrm{HCV}$ infected patients as well as cultured PBMCs [10]. In previous studies we showed not only changes in serum lipid profile in $\mathrm{CHC}$ patients but also in cholesterol expression in PBMCs [11]. Neither this lipid's alteration nor HCV RNA presence in cells was related to miR-122 expression in PBMCs.

This study compares miR-122 and lipoprotein lipase expression in the liver and PBMCs and investigates how these parameters are associated with lipid profile, with HCV load and IFN-gamma, revealing the reverse correlation between lipoprotein lipase and miR-122 expression in the liver of $\mathrm{CHC}$ patients. To the best of our knowledge this study represents the first attempt to evaluate the relationship between miR-122 and LPL expression.

\section{Materials and Methods}

2.1. Participant Enrollment. This study recruited 17 patients with $\mathrm{CHC}$ (genotype 1) and 26 healthy donors (HD). Blood 
samples obtained from both groups, CHC patients and healthy donors, were used for PBMCs and sera isolation. Serum HCV RNA was detected by the Amplicor HCV test, version 2.0 (Roche Diagnostics). In case of $\mathrm{CHC}$ patients, matching human liver specimens from fine needle biopsies were collected. The study was approved by the Bioethical Committee of the Medical University of Lodz (RNN/93/07/kB); signed informed consent from all participants was obtained.

\subsection{Determination of Biochemical Parameters in Sera and} PBMCs. We followed the methods of Sidorkiewicz et al. 2017 [12]. Serum total cholesterol (TC), high-density lipoproteincholesterol (HDL-C), low-density lipoprotein-cholesterol (LDL-C), and triglycerides (TG) were measured enzymatically in Olympus AU 640 and the kits of Olympus. The IFN $\gamma$ concentration in sera was measured using Human IFN $\gamma$ ELISA kit (BioVendor).

Intracellular cholesterol level in PBMC (IC) was evaluated using the cholesterol assay kit, Cholesterol CHOD-PAP (BIOLABO S.A., France) as per manufacturer's recommendation, and the results were normalized to the protein concentration in cell lysates and presented as relative expression of (r.e. IC).

2.3. miR-122 Analysis. For miR-122 analysis, RNA fraction $<200 \mathrm{nt}$ was extracted from PBMCs, using mirVana miRNA Isolation Kit (Ambion), and total RNA from biopsy samples using TRIzol Reagent (Invitrogen) according to the manufacturer's instructions. The reverse transcription (RT) was done, on 10 ng of RNA using the TaqMan MicroRNA Assay specific for miRNA-122 (Applied Biosystems). RT product $(3.3 \mu \mathrm{L})$ was used in Real-Time PCR with miRNA-122specific primers/probe mix and TaqMan Universal PCR Master Mix (Applied Biosystems). The reaction was performed on the ABI Prism 7900 Fast Real-Time PCR System (Applied Biosystems). Relative expression (r.e.) of miR-122 presents the mean Ct value for miRNA-122 Ct, calculated from triplicate reactions and normalized to average $\mathrm{Ct}$ values, obtained for snRNA U6.

2.4. Determination of LPL Expression. LPL expression was determined by Western Blotting. A total of $50 \mu \mathrm{g}$ of protein from PBMCs lysates was subjected to SDS-PAGE, transferred into nitrocellulose, and incubated with rabbit anti-LPL primary antibodies (sc-32885, Santa Cruz Biotechnology, dilution 1:300) and secondary goat anti-rabbit antibodies (sc-2004, Santa Cruz Biotechnology, dilution 1:4000). As a control, goat antibodies against $\beta$-actin (sc-1615, Santa Cruz Biotechnology, dilution 1:300) were used with secondary rabbit anti-goat (1:10000) from Sigma. The positive bands were detected using enhanced chemiluminescence system (ECL) and were quantitatively analyzed using the Bio-Rad Quantity One System. Relative expression (r.e.) of LPL was calculated by normalization to the actin expression for each sample.

2.5. Statistical Analysis. Statistical analysis was performed with STATISTICA 8,0 PL software (StatSoft). Groups were
TABLE 1: Comparison of analyzed parameters in the group of $\mathrm{CHC}$ patients and healthy donors.

\begin{tabular}{|c|c|c|c|}
\hline $\begin{array}{l}\text { Analyzed } \\
\text { parameters } \\
\text { (mean values) }\end{array}$ & $\begin{array}{c}\mathrm{CHC} \\
\text { patients }\end{array}$ & $\begin{array}{l}\text { Healthy } \\
\text { donors }\end{array}$ & $\mathrm{p}$ value \\
\hline Number (M/F) & $17(13 / 4)$ & $26(15 / 11)$ & n.a. \\
\hline Age (ys) & 22,7 & 23,2 & n.a. \\
\hline $\operatorname{ALT}(\mathrm{IU} / \mathrm{ml})$ & 69,18 & 20,6 & 0,003 \\
\hline $\begin{array}{l}\text { IFN gamma } \\
(\mathrm{pg} / \mathrm{ml})\end{array}$ & 4,41 & 5,52 & 0,015 \\
\hline $\mathrm{TC}(\mathrm{mmol} / \mathrm{L})$ & 2,55 & 3,61 & $<0,0001$ \\
\hline LDL-C (mmol/L) & 1,4 & 2,03 & 0,003 \\
\hline $\mathrm{HDL}-\mathrm{C}(\mathrm{mmol} / \mathrm{L})$ & 0,8 & 1,09 & 0,002 \\
\hline $\mathrm{TG}(\mathrm{mmol} / \mathrm{L})$ & 0,77 & 1,1 & $0,16(\mathrm{~ns})$ \\
\hline r.e. IC (PBMCs) & 1,12 & 1,76 & $<0,0001$ \\
\hline $\begin{array}{l}\text { HCV RNA load } \\
(\mathrm{IU} / \mathrm{ml})\end{array}$ & $3,79 \times 10^{5}$ & n.a. & n.a. \\
\hline r.e. LPL (PBMCs) & 2,37 & 1,32 & 0,008 \\
\hline r.e. LPL (Liver) & 3,12 & n.a. & n.a. \\
\hline $\begin{array}{l}\text { r.e. miR-122 } \\
\text { (PBMCs) }\end{array}$ & 0,88 & 0,76 & 0,001 \\
\hline r.e. miR-122 (Liver) & 1,15 & n.a. & n.a. \\
\hline
\end{tabular}

ALT: alanine aminotransferase; F: female; M: male; n.a.: not analyzed; ns: not statistically confirmed result; r.e.: relative expression; ys: years.

compared using the Mann-Whitney $U$ test. Spearman's correlation analysis was applied to measure the strength of relationship between parameters. Differences were considered statistically significant at $\mathrm{p}<0,05$.

All origin data supporting the results reported in this paper are collected and available in the Department of Medical Biochemistry.

\section{Results}

This study recruited 17 patients with $\mathrm{CHC}$ (genotype 1) and 26 healthy donors (HD). General characteristics of studied subjects are included in Table 1 . As presented, the level of total cholesterol, LDL, and HDL fractions in sera as well as intracellular cholesterol level in PBMCs were significantly lower in $\mathrm{CHC}$ patients compared to healthy donors. Similarly, serum IFN $\gamma$ was significantly lower in $\mathrm{CHC}$ patients than in $\mathrm{HD}$. Observed decreased level of triglycerides in $\mathrm{CHC}$ patients was not statistically significant. Comparison of LPL and miR122 expression in PBMCs showed, for both parameters, a higher expression in cells from CHC patients than from HD.

Spearman rank correlation analysis performed on data collected from CHC patients (Table 2) indicated strong reverse correlation for miR-122 expression between liver and PBMCs as well as for LPL expression between these two origins. miR-122 expression in liver was positively correlated with serum HCV RNA load and IFN $\gamma$ and reversely correlated with hepatic LPL expression. We found also the tendency for hepatic LPL expression to be reversely correlated with viral load. Neither for miR-122 nor for LPL expression in PBMCs of CHC patients, significant correlation with $\mathrm{HCV}$ 
TABLE 2: The list of correlations (Spearman rank correlation test) found for data obtained by the analysis of sera (S), liver biopsies (L), and PBMCs (P) samples collected from CHC patients.

\begin{tabular}{|c|c|c|}
\hline $\begin{array}{l}\text { Compared } \\
\text { parameters }\end{array}$ & $\begin{array}{c}\text { Correlation } \\
\text { coefficient value }\end{array}$ & $P$ value \\
\hline $\begin{array}{l}\text { miR-122 (L) vs HCV } \\
\text { RNA (S) }\end{array}$ & $+0,63$ & 0,006 \\
\hline $\begin{array}{l}\operatorname{miR}-122(\mathrm{~L}) \text { vs IFN } \gamma \\
(\mathrm{S})\end{array}$ & $+0,54$ & 0,024 \\
\hline $\begin{array}{l}\text { miR-122 (P) vs HCV } \\
\text { RNA (S) }\end{array}$ & $-0,81$ & 0,026 \\
\hline $\begin{array}{l}\text { miR-122 (P) vs } \\
\text { miR-122 (B) }\end{array}$ & $-0,93$ & 0,001 \\
\hline LPL (L) vs LPL (P) & $-0,56$ & 0,028 \\
\hline $\begin{array}{l}\text { LPL (L) vs miR-122 } \\
\text { (B) }\end{array}$ & $-0,47$ & 0,014 \\
\hline $\begin{array}{l}\text { LPL (L) vs HCV RNA } \\
(\mathrm{S})\end{array}$ & $-0,31$ & $0,06 *$ \\
\hline $\begin{array}{l}\text { LPL (P) vs HCV RNA } \\
(\mathrm{S})\end{array}$ & $+0,42$ & 0,036 \\
\hline
\end{tabular}

* - indicates a tendency.

RNA load was revealed. Additionally, in the group of healthy donors, strong reverse correlation was found between serum IFN $\gamma$ and both TC $(r=-0,52, p=0,008)$ and LDL $(r=-0,42$, $\mathrm{p}=0,039)$, not detected in the group of $\mathrm{CHC}$ patients.

\section{Discussion}

The strategic role of hepatitis $\mathrm{C}$ virus in manipulating of host lipids/lipoproteins metabolism was described [3] as essential for the entry, secretion, and replication of virus. Our results showed that TC, LDL, and HDL fractions, as well as intracellular cholesterol level in PBMCs, were significantly decreased in $\mathrm{CHC}$ patients compared to healthy donors. These data remain in line with previous observations that associates $\mathrm{CHC}$ infections not only with liver steatosis but also with decreased cholesterol expression $[13,14]$. HCV may modulate lipid metabolism in host cells in order to create a more hospitable environment for its own "life cycle".

Concerning IFN, we observed that serum IFN $\gamma$ level was significantly reduced in $\mathrm{CHC}$ patients compared to healthy donors, which remains in agreement with earlier reports $[15,16]$. Additionally, we found that serum IFN $\gamma$ was reversely correlated with total cholesterol and LDL level, but only in the group of healthy donors. Lack of such a relationship in the group of $\mathrm{CHC}$ patients may suggest perturbation between cholesterol metabolism and IFN $\gamma$ signaling. It was shown by others [17] that the alteration of cholesterol pathway may abrogate the IFN-gamma-dependent immune response.

Lipoprotein lipase, which plays a main role in lipoprotein/lipid homeostasis, emerged recently as a host-protecting factor against $\mathrm{HCV}$ infection. Indeed, a strong tendency to opposite correlation between HCV RNA load and hepatic expression of lipoprotein lipase seems to confirm these observations in our study. Lack of such a relationship for LPL in PBMCs can be explained by opposite correlation between LPL expression in liver and PBMCs. Interestingly, while LPL may regulate TG metabolism, no correlation was found between LPL expression and TG level.

According to the suggested role of miR-122 in HCV replication [8], our results demonstrated the positive correlation between the HCV RNA load and miR-122 expression in liver (not in PBMCs). Like in case of LPL, miR-122 showed also opposite expression in the liver and in PBMCs. Hepatic miR-122 was reversely correlated with the expression of lipoprotein lipase. It is especially interesting observation as liver-specific miR-122 is known to promote hepatitis $\mathrm{C}$ virus replication and lipoprotein lipase to protect the host from $\mathrm{HCV}$ infection.

As was mentioned earlier, LPL may suppress HCV infectivity by the breakdown of viral lipid coat and bridging between $\mathrm{HCV}$ and hepatocytes that blocks the viral entry to the cell $[4,6]$. The third mechanism of anti-HCV action of LPL is based on activation of peroxisomal proliferatorsactivated receptor- $\alpha$ (PPAR- $\alpha$ ) signaling pathway [7]. After LPL hydrolysis free fatty acids create ligands for this pathway in target cells. That in turn may cause an antiviral action in infected patients via reduction of viral assembly and secretion. Independently of LPL activity, the same pathway may be triggered directly by alteration of miR-122 expression. The study of Gatfield [18] demonstrated that the knockdown of miR-122 expression resulted in the activation of PPAR- $\alpha$ signaling pathway.

Additionally, we found that miR-122 expression in liver (not in PBMCs) is positively correlated with IFN $\gamma$ concentration. Interestingly, it was found earlier that IFN $\gamma$ is involved in lipoprotein lipase inhibition, at the level of LPL gene transcription [19]. Thus, we cannot exclude that, in CHC patients, IFN-gamma may participate in reducing of LPL expression along with miR-122.

In conclusion, this study provides evidence for opposite expression of both miR-122 and lipoprotein lipase in liver and PBMCs. Hepatic miR-122 expression in CHC patients seems to be of high importance for HCV infection which was evidenced by strong positive relationship between miR122 and HCV RNA load. The reverse relationship between miR-122 and lipoprotein lipase in liver suggests that the modulation of lipoprotein lipase may be another manifestation of the proinfective action of miR-122. Therefore, a future study attempting to explain the mechanism of cross-reactivity between miR-122 and LPL is worth considering.

\section{Data Availability}

The data used to support the findings of this study are available from the corresponding author upon request.

\section{Conflicts of Interest}

The authors declare that they have no conflicts of interest.

\section{Acknowledgments}

This study was conducted with the financial support of the Ministry of Science and Higher Education of Poland 
(N N401098536) and the statutory funds of Department of Medical Biochemistry (503/6-086-01/503-61-001) of Medical University of Lodz.

\section{References}

[1] A. P. Thrift, H. B. El-Serag, and F. Kanwal, "Global epidemiology and burden of HCV infection and HCV-related disease," Nature Reviews Gastroenterology \& Hepatology, vol. 14, no. 2, pp. 122132, 2017.

[2] L. M. Pfeffer, M. A. Madey, C. A. Riely, and J. F. Fleckenstein, "The induction of type i interferon production in hepatitis Cinfected patients," Journal of Interferon \& Cytokine Research, vol. 29, no. 5, pp. 299-306, 2009.

[3] C.-I. Popescu, L. Riva, O. Vlaicu, R. Farhat, Y. Rouillé, and J. Dubuisson, "Hepatitis C virus life cycle and lipid metabolism," Biology, vol. 3, no. 4, pp. 892-921, 2014.

[4] Y. Shimizu, T. Hishiki, K. Sugiyama et al., "Lipoprotein lipase and hepatic triglyceride lipase reduce the infectivity of hepatitis $\mathrm{C}$ virus (HCV) through their catalytic activities on $\mathrm{HCV}$ associated lipoproteins," Virology, vol. 407, no. 1, pp. 152-159, 2010.

[5] Y. Shimizu, T. Hishiki, S. Ujino, K. Sugiyama, K. Funami, and K. Shimotohno, "Lipoprotein component associated with hepatitis C virus is essential for virus infectivity," Current Opinion in Virology, vol. 1, no. 1, pp. 19-26, 2011.

[6] P. Maillard, M. Walic, P. Meuleman et al., "Lipoprotein lipase inhibits hepatitis $\mathrm{C}$ virus (HCV) infection by blocking virus cell entry," PLoS ONE, vol. 6, no. 10, Article ID e26637, 2011.

[7] H.-Y. Sun, C.-C. Lin, P.-J. Tsai et al., "Lipoprotein lipase liberates free fatty acids to inhibit HCV infection and prevent hepatic lipid accumulation," Cellular Microbiology, vol. 19, no. 4, Article ID e12673, 2017.

[8] S. Bandiera, S. Pfeffer, T. Baumert, and M. Zeisel, "miR-122 a key factor and therapeutic target in liver disease," Journal of Hepatology, vol. 62, pp. 448-457, 2015.

[9] C. Esau, S. Davis, S. F. Murray et al., "miR-122 regulation of lipid metabolism revealed by in vivo antisense targeting," Cell Metabolism, vol. 3, no. 2, pp. 87-98, 2006.

[10] I. Castillo, E. Rodríguez-Iñigo, J. Bartolomé et al., "Hepatitis $\mathrm{C}$ virus replicates in peripheral blood mononuclear cells of patients with occult hepatitis C virus infection," Gut, vol. 54, no. 5, pp. 682-685, 2005.

[11] M. Sidorkiewicz, M. Grek, B. Jozwiak, and A. Piekarska, "Decreased level of intracellular cholesterol in peripheral blood mononuclear cells is associated with chronic hepatitis $\mathrm{C}$ virus infection," Virus Research, vol. 178, no. 2, pp. 539-542, 2013.

[12] M. Sidorkiewicz, M. Grek, B. Jozwiak, A. Krol, and A. Piekarska, "The impact of chronic hepatitis $\mathrm{C}$ infection on cholesterol metabolism in PBMCs is associated with microRNA-146a expression," European Journal of Clinical Microbiology \& Infectious Diseases, vol. 36, no. 4, pp. 697-702, 2017.

[13] D. Siagris, M. Christofidou, G. J. Theocharis et al., "Serum lipid pattern in chronic hepatitis C: Histological and virological correlations," Journal of Viral Hepatitis, vol. 13, no. 1, pp. 56-61, 2006.

[14] D. J. Felmlee, M. L. Hafirassou, M. Lefevre, T. F. Baumert, and C. Schuster, "Hepatitis C virus, cholesterol and lipoproteinsimpact for the viral life cycle and pathogenesis of liver disease," Viruses, vol. 5, no. 5, pp. 1292-1324, 2013.
[15] Y. Kondo, V. M. Sung, K. Machida, M. Liu, and M. M. Lai, "Hepatitis $\mathrm{C}$ virus infects $\mathrm{T}$ cells and affects interferon- $\gamma$ signaling in T cell lines," Virology, vol. 361, no. 1, pp. 161-173, 2007.

[16] M. Malaguarnera, I. Di Fazio, A. Laurino, G. Pistone, S. Restuccia, and B. A. Trovato, "Decrease of interferon gamma serum levels in patients with chronic hepatitis C," Biomedicine \& Pharmacotherapy, vol. 51, no. 9, pp. 391-396, 1997.

[17] J. M. Jameson, J. Cruz, A. Costanzo, M. Terajima, and F. A. Ennis, "A role for the mevalonate pathway in the induction of subtype cross-reactive immunity to influenza A virus by human $\gamma \delta$ T lymphocytes," Cellular Immunology, vol. 264, no. 1, pp. 7177, 2010.

[18] D. Gatfield, G. Le Martelot, C. E. Vejnar et al., "Integration of microRNA miR-122 in hepatic circadian gene expression," Genes \& Development, vol. 23, no. 11, pp. 1313-1326, 2009.

[19] S. M. Harris, E. J. Harvey, T. R. Hughes, and D. P. Ramji, "The interferon- $\gamma$-mediated inhibition of lipoprotein lipase gene transcription in macrophages involves casein kinase 2and phosphoinositide-3-kinase-mediated regulation of transcription factors Sp1 and Sp3," Cellular Signalling, vol. 20, no. 12, pp. 2296-2301, 2008. 


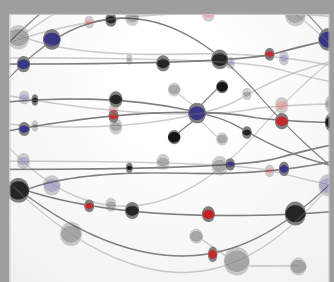

The Scientific World Journal
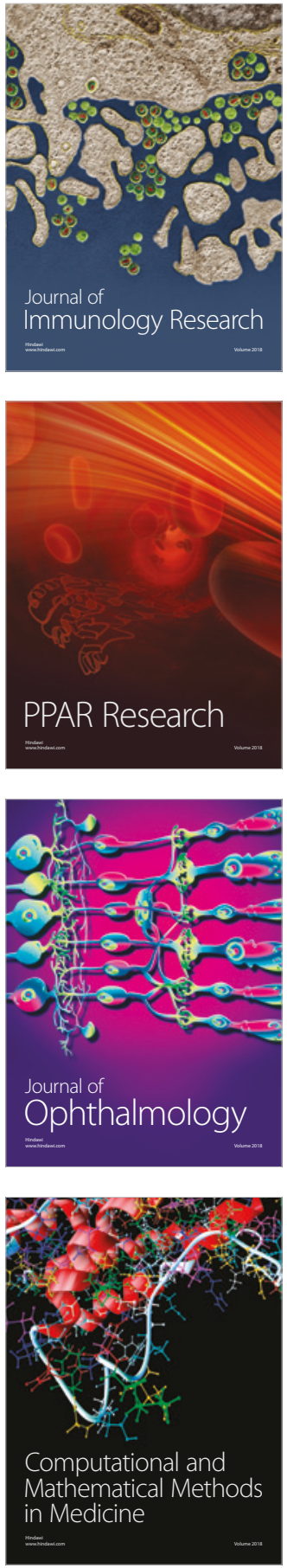

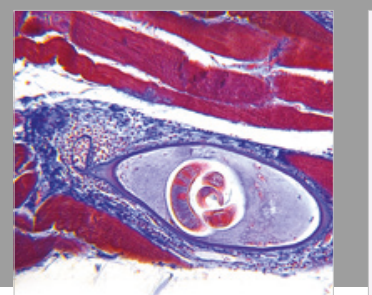

Gastroenterology Research and Practice

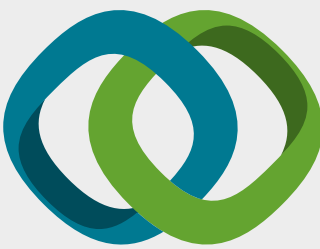

\section{Hindawi}

Submit your manuscripts at

www.hindawi.com
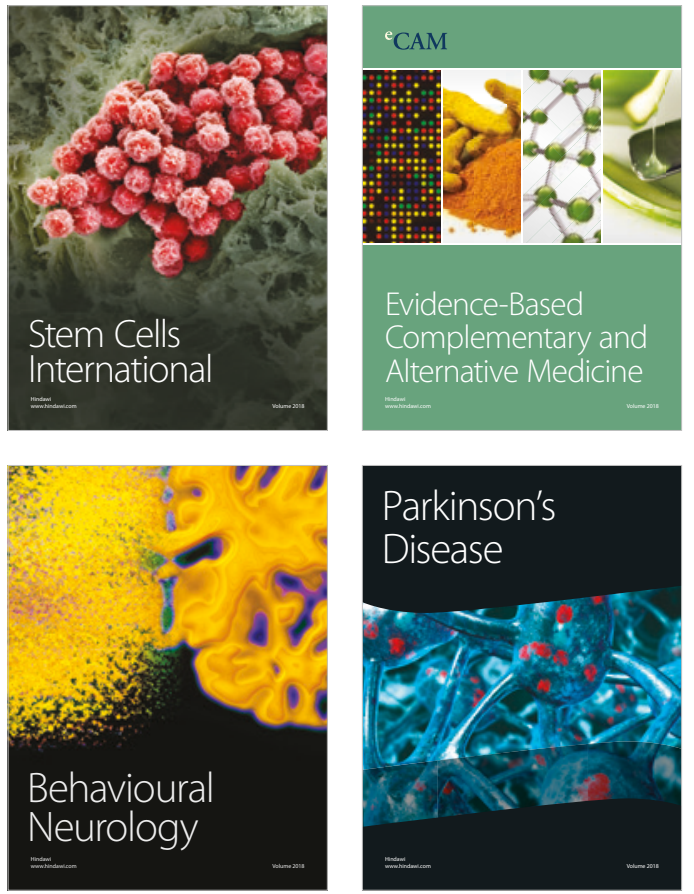

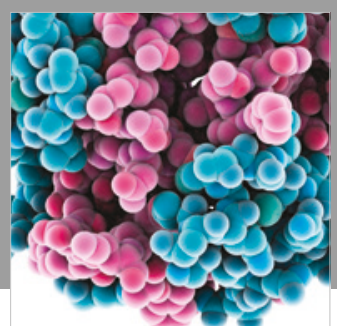

ournal of

Diabetes Research

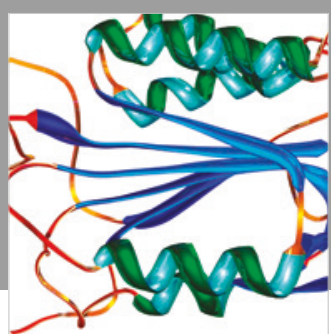

Disease Markers
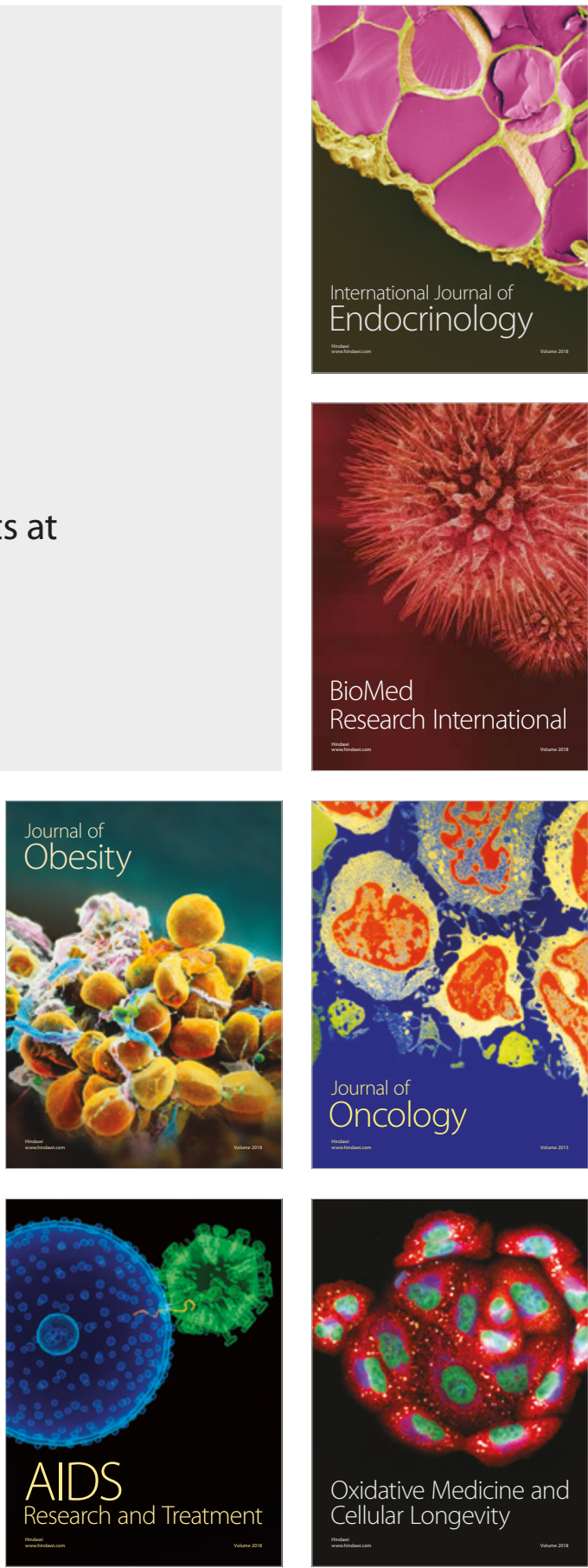